\title{
DIAGNÓSTICO DO MEIO FÍSICO DA FAZENDA SANTA CARLOTA: SOLOS ${ }^{1}$
}

\section{PHYSICAL ENVIRONMENT DIAGNOSIS OF THE SANTA CARLOTA FARM: SOIL}

\author{
Marcio ROSSI ${ }^{2,3}$; Isabel Fernandes de Aguiar MATTOS²; Marina Mitsue KANASHIRO²; \\ Lucas Gonzaga dos SANTOS ${ }^{2}$; Julio Wilson Valcarcel VELLARDI ${ }^{2}$
}

\begin{abstract}
Resumo - com o objetivo de caracterizar e diagnosticar o meio físico da Fazenda Santa Carlota, foram levantados dados geológicos, geomorfológicos, pedológicos, geotécnicos e do clima, valendo-se de revisões bibliográfica e cartográfica, compilação de dados secundários, trabalho de campo e análise e integração de dados. Esses elementos descritos foram caracterizados pela definição de unidades de terreno e pela atribuição de graus de sensibilidade, vinculados principalmente aos solos, ao relevo e à litologia. A área é dominada por relevo amorreado e colinoso, com litologias areníticas/siltíticas e diabásio, que desenvolvem basicamente oito unidades de solos, compostas por Latossolos, Argissolos, Cambissolos e Gleissolos. Apresenta condições do meio físico adequadas ao uso agrossilvopastoril, principalmente nos relevos mais aplanados e colinosos de domínio de diabásio e arenitos. Relativamente ao meio físico, a área estudada apresenta características favoráveis para tornar-se Unidade de Conservação.

Palavras-chave: relevo; litologia; solo; sensibilidade geoambiental.
\end{abstract}

\begin{abstract}
Geological, geomorphological, pedological, geotechnical and climate data were surveyed aiming to characterize and diagnose the physical environment of the Santa Carlota Farm, based on literature review, mapping, compilation of secondary data, field work, and data analysis and integration. The elements were characterized by setting units of land and by assigning degrees of sensitivity, mainly linked to the soil, relief and lithology. The area is dominated by a hilly terrain, with sandstone/siltstone lithologies and diabase, which basically develop eight mapping units composed by Latossolos (Oxisols), Argissolos (Ultisols), Cambissolos (Inceptisols) and Gleissolos (Aquents). The physical environment shows suitability for farming areas use, mainly in the more flattened and hilly reliefs with domain of diabase and sandstones. By physical environment the area has favorable characteristics to become Conservation Unit.
\end{abstract}

Keywords: relief; lithology; soil; geoenvironmental sensitivity.

\section{INTRODUÇÃO}

Para se conservar os ambientes naturais, é necessário, antes de tudo, conhecer e entender os elementos que os compõem, para que qualquer atitude, no sentido de manejar e planejar o uso da área, seja efetuada com embasamento técnico e científico.

Desta forma, Rossi et al. (2005) evidenciam que o conhecimento da relação entre os elementos componentes da paisagem facilita a compreensão da dinâmica, da evolução desses locais, do manejo e do planejamento. Dentre os fatores que interferem na formação e no entendimento da paisagem, o solo desempenha papel fundamental, fornecendo suporte mecânico e nutrientes para o estabelecimento e o desenvolvimento das plantas, além de refinar o modelado do relevo.

Diversos trabalhos nesse sentido têm sido desenvolvidos, buscando a caracterização do ambiente e, em especial, do meio físico (Zornoff et al., 2011; Santos et al., 2011; Villela, 2012).

\footnotetext{
${ }^{1}$ Recebido para análise em 21/10/2013. Aceito para publicação em 22/8/2014.

${ }^{2}$ Instituto Florestal, Rua do Horto, 931, 02377-000 São Paulo, SP, Brasil.

${ }_{3}$ Autor para correspondência: Marcio Rossi - rossi@if.sp.gov.br
} 
A Fazenda Santa Carlota situa-se na região abrangida pela Bacia do Rio Pardo, no município de Cajuru, São Paulo. Localizada no município de Cajuru-SP, apresenta glebas de vegetação nativa ainda em bom estado de conservação, constituindo-se em remanescentes florestais de importância para a região. Está inserida em domínio de relevo de colinas e, portanto, de fácil ocupação.

A região, situada no nordeste do Estado de São Paulo, teve sua ocupação e desenvolvimento iniciados a partir da metade do século XIX, com a cultura cafeeira, que, em busca de solos mais férteis para o plantio do café, avança desmatando grandes áreas de florestas e cerrados. Na sequência, há também o desenvolvimento da cultura algodoeira e da pecuária bovina, direcionadas à exportação, facilitadas pelo estabelecimento de uma rede ferroviária e rodoviária, que liga o interior à capital e ao Porto de Santos. Essa ocupação hoje inclui outras atividades agrossilvopastoris, como, por exemplos, os reflorestamentos, a cana-de-açúcar, a soja e a pecuária, que dividem espaço com o café.

Apesar do intenso desmatamento verificado na região, são ainda observados alguns importantes fragmentos florestais, dentre os quais se inclui o encontrado na Fazenda Santa Carlota, alvo do presente estudo.

Neste contexto, o objetivo do trabalho é caracterizar e diagnosticar o meio físico da Fazenda Santa Carlota, com enfoque nos solos, buscando a incorporação da área como unidade de conservação.

\section{MATERIAIS E MÉTODOS}

A área de estudo localiza-se ao sul do município de Cajuru-São Paulo e abrange a Fazenda Santa Carlota, entre as latitudes $21^{\circ} 19^{\prime} 45^{\prime \prime} \mathrm{S}$ a $21^{\circ} 27^{\prime} 15^{\prime \prime} \mathrm{e}$ as longitudes $47^{\circ} 13^{\prime} 45^{\prime \prime} \mathrm{W}$ a $47^{\circ} 19^{\prime} 15^{\prime \prime}$ (Figura 1). Possui 3.183,73 ha, porém, para entendimento da área objeto e da paisagem, foram coletadas informações sobre o meio físico também em sua área envoltória.

Os estudos dos solos foram orientados para a caracterização expedita e a espacialização, quando possível, estabelecendo as principais associações destes solos com o relevo e a geologia. Foram utilizadas fotografias aéreas, imagens do satélite SPOT e ortofotos digitais, para programar os trabalhos de campo, interpretar as unidades de paisagem e indicar os locais de observações, tendo como mapa-base, a carta topográfica 1:50.000.

Para compreender a distribuição e o comportamento dos atributos do meio físico, foi elaborada uma análise integrada desses atributos, de acordo com Pires Neto (1992). Esta compreendeu a compilação de informações sobre o substrato rochoso (Perrotta et al., 2005; Bistrichi et al., 1981), o relevo (Ponçano et al., 1981; Ross e Moroz, 1997), os solos (Oliveira et al., 1999) e a geotecnia (Nakazawa et al., 1994), de modo a oferecer subsídios importantes para o entendimento da paisagem. As informações foram complementadas com levantamentos de campo, com observação do relevo da litologia e dos solos de 64 pontos.

O método de prospecção adotado compreendeu investigações ao longo de transecções. Nestas, as observações foram efetuadas a fim de detectar o máximo de variações da paisagem, compreendendo particularidades fisiográficas, tais como geomorfologia e drenagem superficial, bem como aspectos relacionados à vegetação e ao uso da terra. Os pontos observados em campo foram georreferenciados e os solos foram descritos, caracterizados e classificados segundo Santos et al. $(2005,2013)$, demonstrando sua distribuição a partir da litologia e do relevo.

\subsection{Caracterização do meio físico}

\subsubsection{Geologia}

O Estado de São Paulo faz parte da Plataforma Sul-Americana e possui registro geológico bastante extenso, abrangendo desde o período Pré-Cambriano (Arqueano) até o Quaternário (Almeida et al., 1981). Esta plataforma está embasada no complexo cristalino formado por rochas ígneas e metamórficas, configurada em dois compartimentos: o Escudo Atlântico, terrenos onde o embasamento cristalino está exposto com restritas coberturas sedimentares, e a Bacia do Rio Paraná, porção de cobertura da plataforma devido à sua subsidência, que permitiu a acumulação de grande espessura de sedimentos e lavas basálticas. 


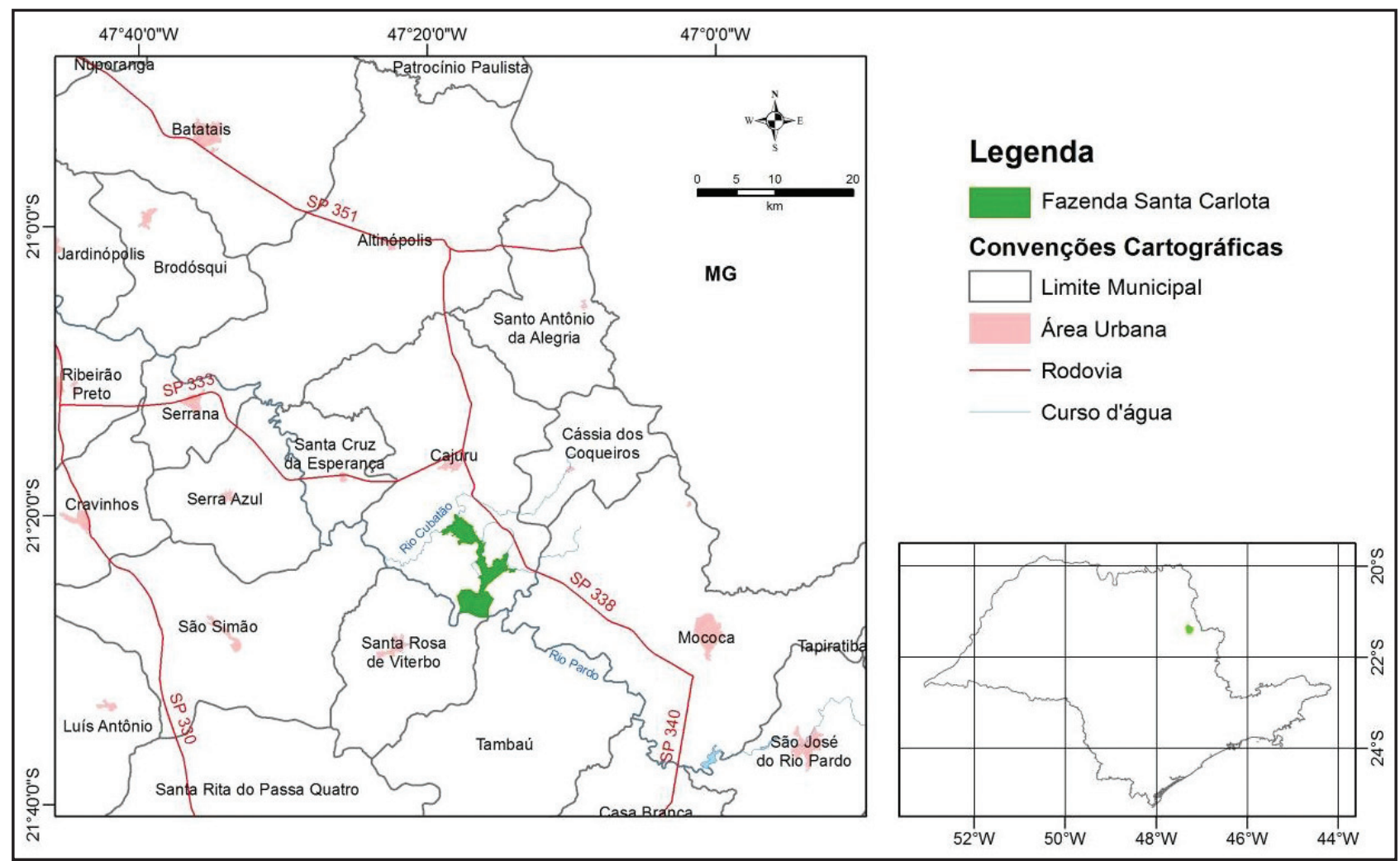

Figura 1. Localização da área de estudo no município de Cajuru e no Estado de São Paulo. Figure 1. Study area located in the municipality of Cajuru, state of Sao Paulo, southeastern Brazil.

A Fazenda Santa Carlota possui uma formação geológica diversa e, segundo o Mapa Geológico do Estado de São Paulo, da Companhia de Pesquisa de Recursos Minerais - CPRM (Perrotta et al., 2005), ocorrem seis unidades litoestatigráficas: Formação Aquidauana; Formação Tatuí; Formação Corumbataí; Formação Piramboia; Intrusivas basálticas tabulares, e Sedimentos aluvionares (Figura 2).

A Formação Aquidauana, pertencente ao Grupo Itararé, são depósitos continentais formados por diversas litologias, que se alternam vertical e horizontalmente, predominando arenitos e siltitos avermelhados, e, secundariamente, conglomerados, folhelhos vermelhos ou esverdeados, ritmitos e diamictitos (Almeida et al., 1981).

Nos depósitos da Formação Tatuí, Grupo Guacá, predominam siltitos e, subordinadamente, camadas de arenitos finos, em parte concrecionados, calcário e sílex; apresentam estratificação plano-paralela, de cor vermelha arroxeada na parte inferior e esverdeada na parte superior (Bistrichi et al., 1981).

O Grupo Passa Dois está representado pela Formação Corumbataí, formado por depósitos possivelmente marinhos de planícies de marés. A litologia é composta por folhelhos e siltitos cinzas, arroxeados ou avermelhados, com intercalações de bancos carbonáticos e silexítos, e camadas de arenito fino (Bistrichi et al., 1981).

A Formação Piramboia é caracterizada por arenitos finos a médios, avermelhados, de estratificação cruzada ou plano-paralela, na qual comumente se observam marcas de ondas ou correntes. Ainda estão presentes níveis de folhelhos e arenitos argilosos de cores variadas e raras intercalações de natureza areno-conglomerática. Esses materiais têm origem fluvial e de planícies de inundação (Almeida et al., 1981).

A unidade das Intrusivas básicas tabulares, pertencente ao Grupo São Bento, é formada por soleiras diabásicas e diques básicos em geral, ocorrendo diabásios, dioritos pórfiros, lamprófilos, andesitos, monzonitos pórfiros e traquiandesitos, que sustentam os relevos residuais da área.

Ocorrem, também, Depósitos Aluvionares constituídos por areias inconsolidadas de granulação variável, argilas e cascalheiras fluviais, distribuídas sobre depósitos de calha ou terraços. Almeida et al. (1981) 


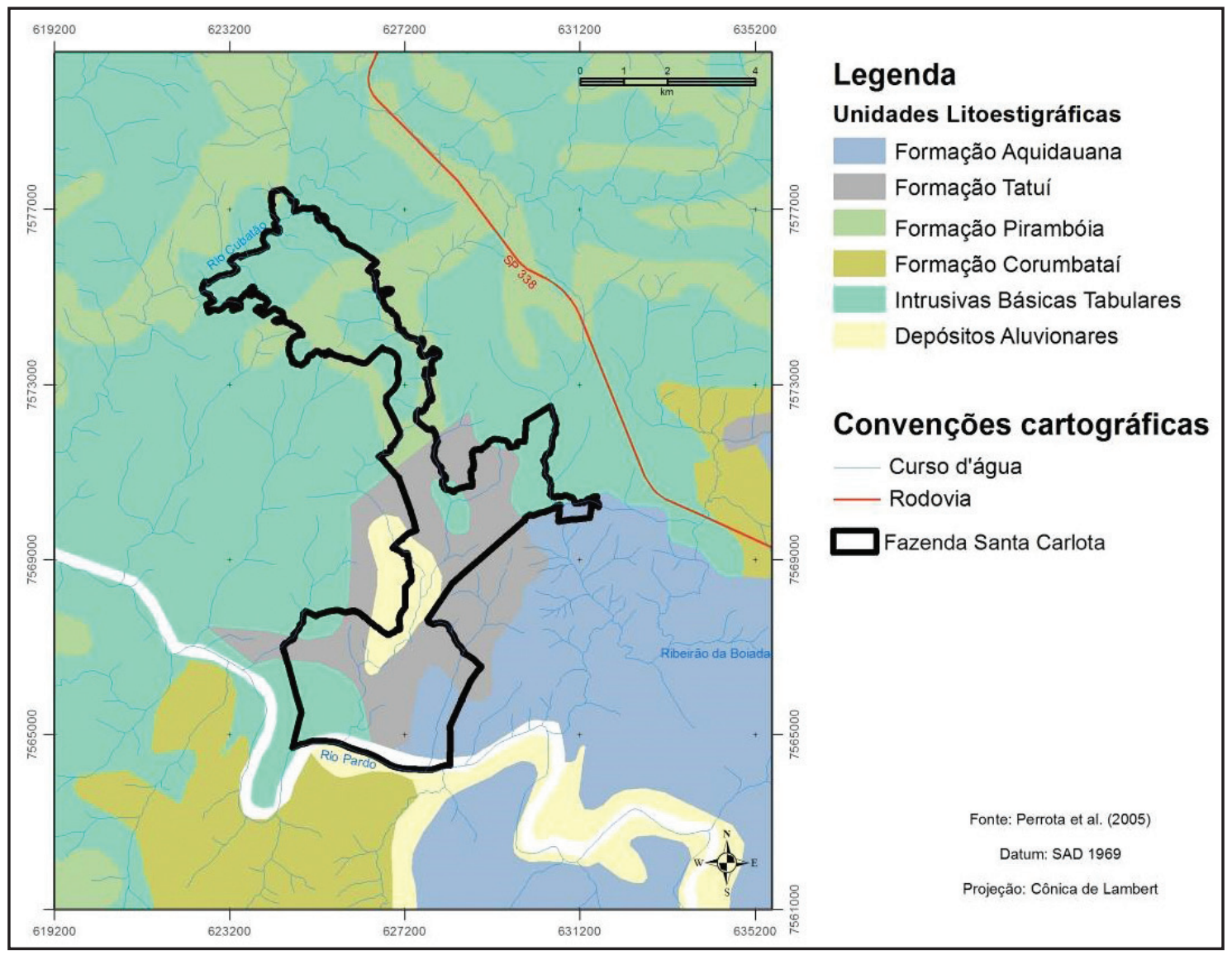

Figura 2. Mapa geológico.

Figure 2. Geological map.

classificam os sedimentos localizados no centro-sul da área como Sedimentos Indiferenciados, caracterizados por depósitos continentais elúvio-coluvionares associados a encostas de natureza areno-argilosa.

\subsubsection{Geomorfologia}

O município de Cajuru situa-se na Bacia do Rio Paraná, sobre a Depressão Periférica, no limite com o Planalto Ocidental, abrangendo a Zona de Mogi-Guaçu e as escarpas das Cuestas Basálticas. A Depressão Periférica e as Cuestas foram originadas pela ocorrência de rochas basálticas na Bacia do Rio Paraná, separando as rochas paleozoicas e mesozoicas dos arenitos cretáceos, que, por erosão diferencial, geraram, respectivamente, ampla escavação e as vertentes escarpadas das cuestas.

A Zona de Mogi-Guaçu corresponde à porção norte da Depressão Periférica e abrange a Bacia do Rio Mogi-Guaçu. Devido ao seu pequeno desenvolvimento lateral, é a zona que representa mais nitidamente o aspecto de depressão. Nesta unidade, predominam formas denudacionais de colinas de topos tabulares amplos.

As Cuestas Basálticas são caracterizadas por relevo escarpado nos limites com a Depressão Periférica e grandes plataformas de relevos suavizados, inclinados em direção à calha do Rio Paraná, em seu reverso (Ponçano et al., 1981). Ross e Moroz (1997) delimitam as Cuestas Basálticas em diversas unidades, conforme as variações fisionômicas regionais. A área estudada abrange a unidade Patamares Estruturais de Ribeirão Preto, com relevo de colinas amplas e baixas, com topos tabulares, e os Planaltos Residuais de Franca e Batatais, 
caracterizados por colinas de topos aplanados, localizados em cotas altimétricas mais altas que as terras circundadas, entre 800 e $1.100 \mathrm{~m}$.

Ponçano et al. (1981) reconhecem quatro diferentes tipos de relevo: de Agradação; de Degradação, em planaltos dissecados; Residuais, suportados por litologias particulares, e de Transição. Dentro destas quatro tipologias, foram identificadas sete morfologias (Figura 3).

O Relevo de Agradação é manifesto em terrenos baixos e mais ou menos planos, sujeitos a inundações periódicas. Essa morfologia do relevo, de natureza continental, denominada Planície Aluvial, ocorre na área junto à margem do Rio Pardo.

A atuação contínua, sobre as áreas planálticas em São Paulo, criou os Relevos de Degradação, em planaltos dissecados, que estão divididos em cinco categorias: colinoso, morrotes, morros, morros com encostas suavizadas e montanhas. Na área que abrange a Fazenda Santa Carlota, estão presentes as três primeiras categorias citadas.

O Relevo Colinoso é predominante na área, apresentando Colinas Médias, caracterizadas por declividades de até 15\%; amplitudes locais inferiores a $100 \mathrm{~m}$; topos aplainados; vertentes com perfis convexos a retilíneos, e interflúvios de 1 a $4 \mathrm{~km}^{2}$. A densidade de drenagem varia de média (5-30 cursos d'água em $\left.10 \mathrm{~km}^{2}\right)$ a baixa (0-5 cursos d'água em $10 \mathrm{~km}^{2}$ ), com padrão sub-retangular, vales abertos a fechados, planícies aluviais interiores restritas e presença eventual de lagos perenes ou intermitentes - drenagem fechada (Ponçano et al., 1981).

O Relevo de Morrotes é visto na forma de Morrotes Alongados e Espigões, no qual predominam declividades acima de 15\% (média a alta) e amplitudes locais inferiores a $100 \mathrm{~m}$. Os topos são angulosos

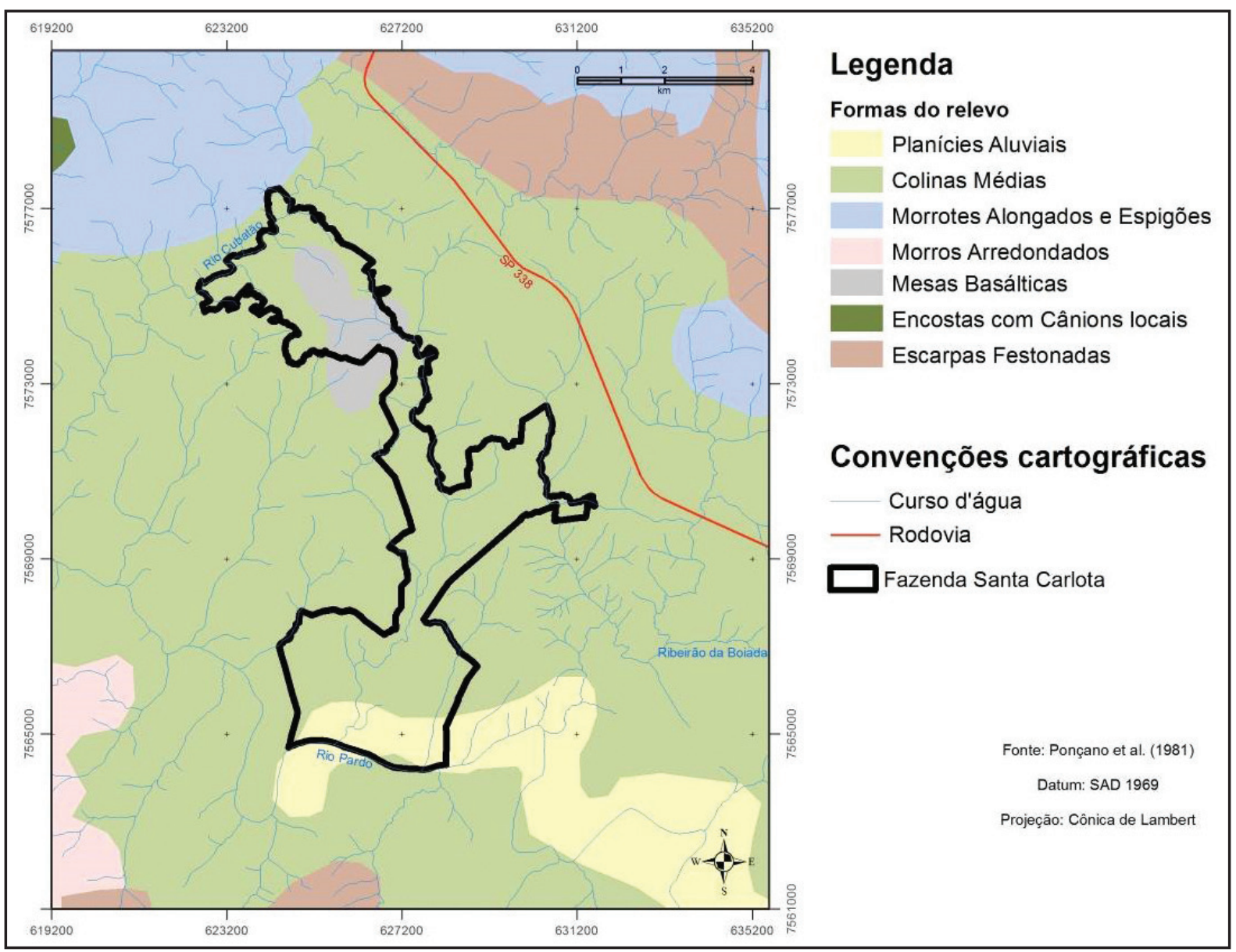

Figura 3. Mapa geomorfológico.

Figure 3. Geomorphological map. 
a achatados, as vertentes são ravinadas, com perfis retilíneos, e geralmente há interflúvios sem orientação preferencial. A drenagem varia de média a alta (mais que 30 cursos d'água em $10 \mathrm{~km}^{2}$ ), a densidade com padrão dendrítico e vales fechados (Ponçano et al., 1981). Encontra-se ao norte da área de estudo.

O Relevo de Morros mostra-se como Morros Arredondados, que possuem declives médios a altos e amplitudes locais de 100 a $300 \mathrm{~m}$, com topos arredondados e localmente achatados, vertentes com perfis convexos a retilíneos, localmente ravinados, com diversas exposições de rocha e formação de espigões curtos locais. A drenagem é de média densidade com padrão dendrítico a subdendrítico e vales fechados (Ponçano et al., 1981). Está presente na porção sudoeste da área envoltória à fazenda.

Ao norte da Fazenda Santa Carlota, ocorre relevo residual suportado por litologia particular; no caso, maciços básicos denominados de Mesas Basálticas. Esses morros, testemunhos isolados, possuem topos aplanados e arredondados com vertentes de perfis retilíneos, muitas vezes com trecho escarpado e exposições de rocha. A drenagem é de média densidade com padrão pinulado e subparalelo, em vales fechados (Ponçano et al., 1981).

Ocorrem, ainda, dois tipos de relevo de transição: a noroeste, as Encostas com Cânions locais, com encostas escarpadas, declives médios e amplitudes maiores que $100 \mathrm{~m}$, com vertentes de perfis retilíneos a convexos e trechos escarpados, e drenagem de média densidade com padrão pinulado, em vales fechados, que localmente formam cânions. A nordeste e sudeste da área, ocorrem Escarpas Festonadas, onde predominam declividades altas e amplitudes maiores que $100 \mathrm{~m}$, desfeitas em anfiteatros separados por espigões, com topos angulosos e vertentes com perfis retilíneos. Drenagem de alta densidade com padrão subparalelo a dendrítico e vales fechados (Ponçano et al., 1981).

\subsubsection{Pedologia}

A região, segundo Oliveira et al. (1999), apresenta domínio de solos do tipo latossolo vermelho (antigo latossolo roxo e latossolo vermelho-escuro), com fertilidade relativamente baixa (distrófico), de textura argilosa e média, em relevo suave ondulado, ondulado e forte ondulado. Segundo os autores, são cinco unidades mapeadas em escala generalizada (Figura 4): LV13, LV19, LV49, RQ4 e RU1.

O Latossolo Vermelho LV 13 é Distroférrico, ou seja, com saturação por bases inferior a 50\% e teores de $\mathrm{Fe}_{2} \mathrm{O}_{3}$ variando entre $180 \mathrm{~g} / \mathrm{kg}$ a $360 \mathrm{~g} / \mathrm{kg}$ na maior parte dos $100 \mathrm{~cm}$ iniciais do horizonte $\mathrm{B}$ (Santos et al., 2013), apresenta horizonte A moderado (não se enquadra nas demais variações de horizontes A, segundo OLIVEIRA, 2008) e textura argilosa (classes texturais com mais de 35\% de argila), e ocorre em relevo forte ondulado (superfície de topografia movimentada, formada por outeiros ou morros e raramente colinas com declives fortes, variando de 20 a 45\% (Embrapa, 1998 apud Oliveira et al., 1999, p. 15) e ondulado (conjunto de colinas ou outeiros que apresentam declives moderados, variando de 8-20\% (Embrapa, 1998 apud Oliveira et al., 1999, p. 15). Aparece em uma faixa do extremo leste até a porção central da fazenda.

A unidade LV 19 é uma associação entre um Latossolo Vermelho Distroférrico de textura argilosa e um Latossolo Vermelho Distrófico (solos com saturação por bases baixa, inferior a $50 \%$, no primeiro metro do horizonte B, segundo Santos et al., 2013) de textura média (classes texturais ou parte delas que possuem mais de $15 \%$ de areia e menos de $35 \%$ de argila). Ambos possuem horizonte A moderado e se desenvolvem em relevo suave ondulado (conjunto de colinas ou outeiros com declives variando de 3-8\%, segundo Embrapa, 1998 apud Oliveira et al., 1999, p. 15) e ondulado.

O LV 49 está sobre relevo suave ondulado e se concentra na porção central e no sudeste da área. Esta unidade é composta por Latossolos Vermelhos e Latossolos Vermelho-Amarelos, ambos distróficos de textura média e com horizonte A moderado (Oliveira et al., 1999).

A Unidade de solos RQ 4 é formada pela associação de Neossolo Quartzênico Órtico (solos formados sem a influência de um lençol freático, segundo Santos et al. 2013), classe textural areia ou areia franca em todos os horizontes - pelo menos até a profundidade de $150 \mathrm{~cm}$ - e essencialmente quartzosos, com horizonte A fraco (horizonte mineral pouco desenvolvido, de acordo com Oliveira, 2008) e moderado, com o Latossolo Vermelho-Amarelo, com horizonte A moderado e textura média. Ambos são distróficos e aparecem sobre relevo 


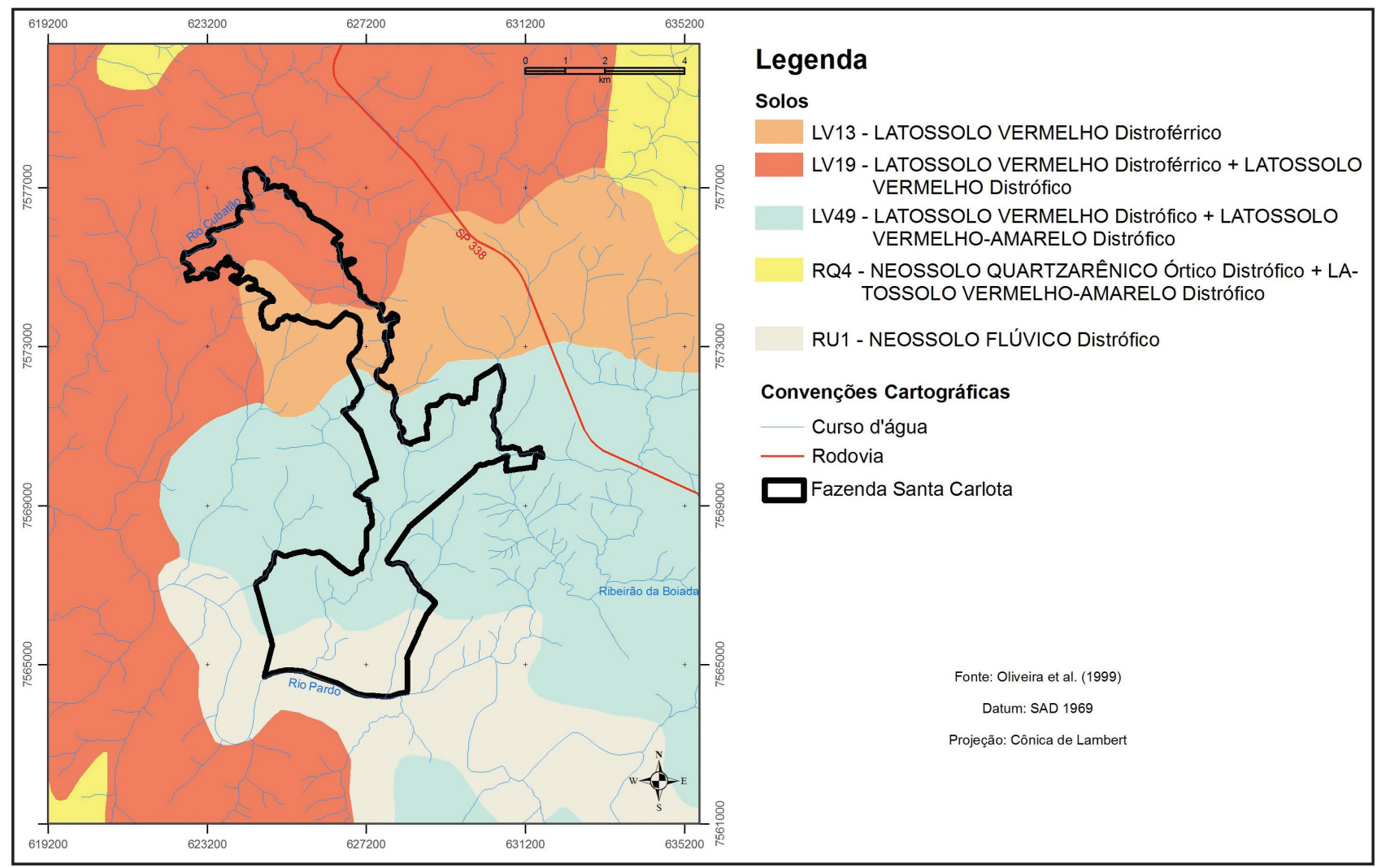

Figura 4. Mapa pedológico.

Figure 4. Pedological map.

suave ondulado e plano (superfície de topografia esbatida ou horizontal, com declividades variando de 0 a 3\%, de acordo com Embrapa, 1998 apud Oliveira et al., 1999, p. 15). Estão representados por pequenas manchas a nordeste, noroeste e sudoeste da área envoltória da Fazenda Santa Carlota (Oliveira et al., 1999).

Os Neossolos Flúvicos (RU 1) são distróficos, de textura argilosa e média, com horizonte A moderado. Estão presentes em relevos de várzea e, na área de estudo, acompanham a várzea do Rio Pardo embasados em litologias menos resistentes, formadas principalmente por areias, arenitos e siltitos (Oliveira et al., 1999).

\subsubsection{Geotecnia}

A partir dos processos geotécnicos aos quais os terrenos estão sujeitos, identificados pela Carta Geotécnica do IPT (Nakazawa et al., 1994), foram reconhecidas cinco unidades geotécnicas para a área de estudo (Figura 5).

O primeiro compartimento é composto por terrenos com suscetibilidade muito alta a processos erosivos, devido ao embasamento geológico de caráter sedimentar, predominando arenitos. O relevo característico é formado por colinas médias, morrotes e morros com declividade variando entre 12 e $20 \%$. A erosão pode ser desencadeada por desmatamento, manejo inadequado dos solos agrícolas e, principalmente, por lançamento de águas superficiais sem medidas e obras de controle adequadas. Estas ações provocam o desenvolvimento de sulcos e ravinas no terreno, que podem progredir para voçorocas ramificadas de dimensão média, com profundidade média em torno de $10 \mathrm{~m}$. Esses processos erosivos geram grande aporte de sedimentos nos cursos 
d'água, causando assoreamento intenso. Para essas áreas, recomendam-se técnicas de manejo conservacionista do solo e ações preventivas e corretivas relacionadas à proteção superficial e à drenagem (Nakazawa et al., 1994).

A segunda compartimentação apresenta terrenos cujo processo dominante é a erosão, descrita acima, mas também estão sujeitos ao processo de expansão e contração de solos. Esse processo secundário

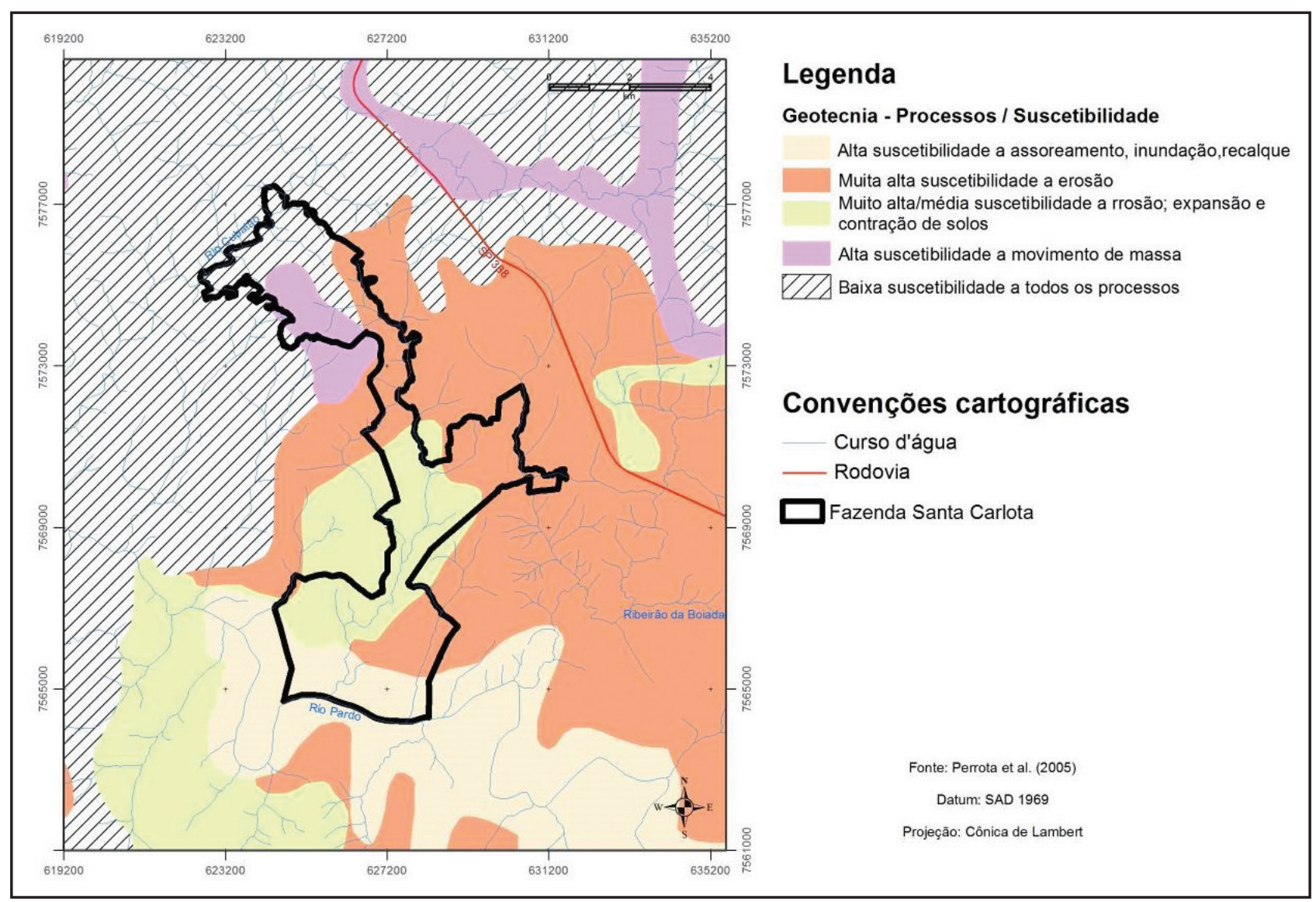

Figura 5. Mapa geotécnico.

Figure 5. Geotechnical map.

predomina em litologias com presença significativa de argilo-minerais expansivos. A expansão e a contração da rocha ou do solo geram problemas, principalmente, na abertura de estradas, pois causam a instabilidade dos taludes por desagregação superficial ou por empastilhamento. Dificilmente, este processo ocasiona problemas em relação à fundação. Para isso, é necessária, além da presença dos argilo-minerais expansivos, a exposição a ciclos de umedecimento e ressecamento, danificando as obras com edificação direta. Para a ocupação desses terrenos, sugerem-se cuidados específicos durante a execução de terraplanagens - quando ocorre a exposição destes materiais às intempéries - e técnicas adequadas de fundação das edificações (Nakazawa et al., 1994).

A outra unidade identificada corresponde a terrenos com alta suscetibilidade a movimentos de massa. Estes são constituídos por relevo de escarpas sustentadas por rochas basálticas e sedimentares, em que os processos estão restritos às porções mais enérgicas do relevo. Estas áreas escarpadas estão ocupadas principalmente por florestas naturais e de reflorestamento, enquanto que, no sopé das escarpas, encontramse estradas, pastagens e agricultura. Na unidade, os movimentos de massas naturais são pouco frequentes e os principais são escorregamentos e quedas de blocos. A instabilização de taludes é mais comum e tais 
processos são quase que exclusivamente induzidos por intervenções, principalmente durante a construção de estradas. Para essa unidade, é recomendada a conservação da cobertura florestal, além de obras para o controle dos movimentos induzidos pelas intervenções no meio físico, como a manutenção dos sistemas viários (Nakazawa et al., 1994).

Os terrenos localizados ao longo de uma porção do Rio Pardo estão sujeitos a problemas de inundações - do tipo fluvial, que atingem as várzeas, e pluvial, atingindo os terraços; recalques excessivos e diferenciais, por adensamento de argilas moles e turfosas; assoreamento dos cursos d'água, por sedimentos gerados por erosão à montante, e erosão fluvial, por solapamento das margens dos rios. Esta unidade ocupa áreas praticamente planas, pertencentes às planícies aluviais interiores e constituídas por sedimentos de texturas variadas. As recomendações para o uso do solo referem-se a medidas de controle de erosão das margens e de controle de inundações, entre outras, que buscam mitigar os problemas relacionados ao uso urbano (Nakazawa et al., 1994).

Ainda ocorrem áreas com baixa suscetibilidade a todos os processos analisados. Nestes terrenos, os processos são localizados, pouco frequentes e pouco significativos. Estão presentes, principalmente, em áreas onde o relevo é colinoso e os solos são mais resistentes à erosão, aparecendo assim nas bacias sedimentares terciárias, na Depressão Periférica e em algumas áreas basálticas. Não são feitas recomendações específicas para esta compartimentação além de ações normalmente adotadas, como reconhecimento de campo e investigações localizadas (Nakazawa et al., 1994).

\subsubsection{Clima}

Segundo a classificação climática de Köppen, o município de Cajuru possui clima temperado úmido com inverno seco e verão quente (Cwa). A temperatura média do mês mais frio (julho) é de $17,9^{\circ} \mathrm{C}$ e a temperatura média do mês mais quente (fevereiro) é de $23,7^{\circ} \mathrm{C}$.

Quanto à ocorrência das chuvas, são caracterizados dois períodos distintos: um chuvoso, de outubro a março, representando $84,94 \%$ do total anual, e outro seco, de abril a setembro. Dezembro e janeiro apresentam maior índice pluviométrico, enquanto julho e agosto são os meses com menor precipitação.

Observa-se, no balanço hídrico climatológico (Tabela 1 e Figura 6), que a evapotranspiração real é elevada $(920 \mathrm{~mm})$ e próxima da evapotranspiração potencial, correspondendo a $67,89 \%$ da precipitação anual. A deficiência hídrica do solo é de $94 \mathrm{~mm}$ e ocorre de abril a setembro, enquanto que, para os meses de dezembro a março, há um excesso de água de $435 \mathrm{~mm}$.

\section{RESULTADOS}

A área da Fazenda Santa Carlota apresenta litologia de Intrusivas Básicas Tabulares (diabásio), em Relevo Residual, das formações Tatuí (siltito), Piramboia (arenito) e Aquidauana (arenito/siltito), em Relevo de Colinas e Morrotes, e de Depósitos Aluvionares, em planícies fluviais. A distribuição dos solos na área pode ser observada através das formas do relevo e da litologia, uma vez que a interação desses elementos reflete diretamente na textura, na profundidade e nos fluxos hídricos, dentro do mesmo clima e tempo de exposição.

Como resultados, foi produzido o mapa de solos (Figura 7), contendo oito unidades de mapeamento com 11 classes de solos (Tabela 2); observe-se que as Tabelas 3 a 7 sintetizam e correlacionam os solos e os elementos de geologia e geomorfologia, apresentando as potencialidades, restrições e sensibilidade geoambiental das unidades de terreno. 
ROSSI, M. et al. Diagnóstico do meio físico da Fazenda Santa Carlota: solos

Tabela 1. Balanço hídrico climatológico do município de Cajuru. Fonte: Banco de dados climáticos do Brasil. EMBRAPA. Table 1. Climatological water balance of the municipality of Cajuru. Source: Brazilian climate database. EMBRAPA.

\begin{tabular}{|c|c|c|c|c|c|c|}
\hline & $\mathrm{T}\left({ }^{\circ} \mathrm{C}\right)$ & $\mathrm{P}(\mathrm{mm})$ & ETP $(\mathrm{mm})$ & ETR (mm) & $\mathrm{DEF}(\mathrm{mm})$ & $\mathrm{EXC}(\mathrm{mm})$ \\
\hline Janeiro & 23,6 & 258 & 114 & 114 & 0 & 144 \\
\hline Fevereiro & 23,7 & 229 & 105 & 105 & 0 & 124 \\
\hline Março & 23,2 & 160 & 106 & 106 & 0 & 54 \\
\hline Abril & 21,4 & 54 & 80 & 77 & 3 & 0 \\
\hline Maio & 19,2 & 43 & 61 & 56 & 5 & 0 \\
\hline Junho & 18 & 24 & 48 & 38 & 10 & 0 \\
\hline Julho & 17,9 & 17 & 49 & 31 & 18 & 0 \\
\hline Agosto & 19,8 & 17 & 64 & 31 & 33 & 0 \\
\hline Setembro & 21,4 & 49 & 79 & 55 & 24 & 0 \\
\hline Outubro & 22,4 & 129 & 96 & 96 & 0 & 0 \\
\hline Novembro & 22,7 & 147 & 100 & 100 & 0 & 0 \\
\hline Dezembro & 23,1 & 228 & 112 & 112 & 0 & 114 \\
\hline Total & 256,4 & 1.355 & 1.014 & 920 & 94 & 435 \\
\hline Média & 21,4 & 113 & 85 & 77 & 8 & 36 \\
\hline
\end{tabular}

T - temperatura; P - precipitação; ETP - evapotranspiração potencial; ETR - evapotranspiração real; DEF - deficiência hídrica; EXC - excedente hídrico.

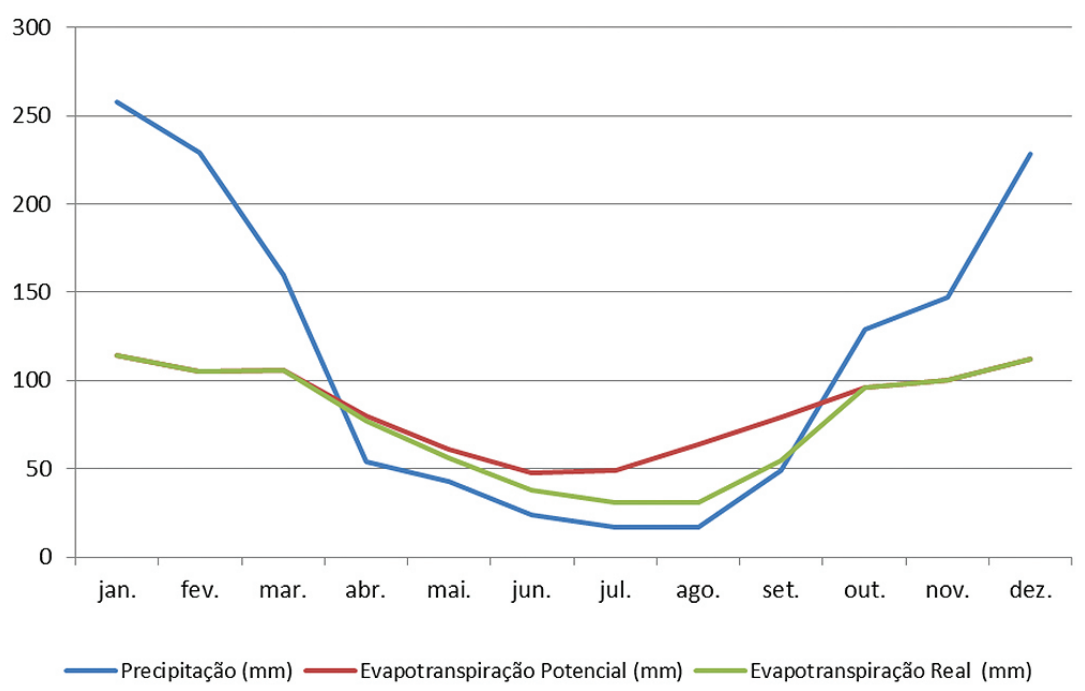

Figura 6. Representação gráfica do balanço hídrico climatológico do município de Cajuru, São Paulo. Figure 6. Graphic of the water balance in the municipality of Cajuru state of Sao Paulo.

A seguir, são apresentadas as descrições gerais das classes de solos observadas.

\section{Latossolos}

Solos constituídos por material mineral, com horizonte B latossólico abaixo de horizonte superficial A moderado ou proeminente. São solos com avançado estágio de intemperização, muito evoluídos, virtualmente destituídos de minerais primários ou secundários. Variam de fortemente a bem drenados.

Latossolo Vermelho

Ocorre em relevo colinoso, com declives inferiores a $10 \%$ e com teores de $\mathrm{Fe}_{2} \mathrm{O}_{3}$ até $18 \%$, em Cerradão, Ecótono e Floresta Estacional Semidecidual. Na área, se desenvolvem em litologia de siltito e arenito, e destas em contato com o diabásio. 


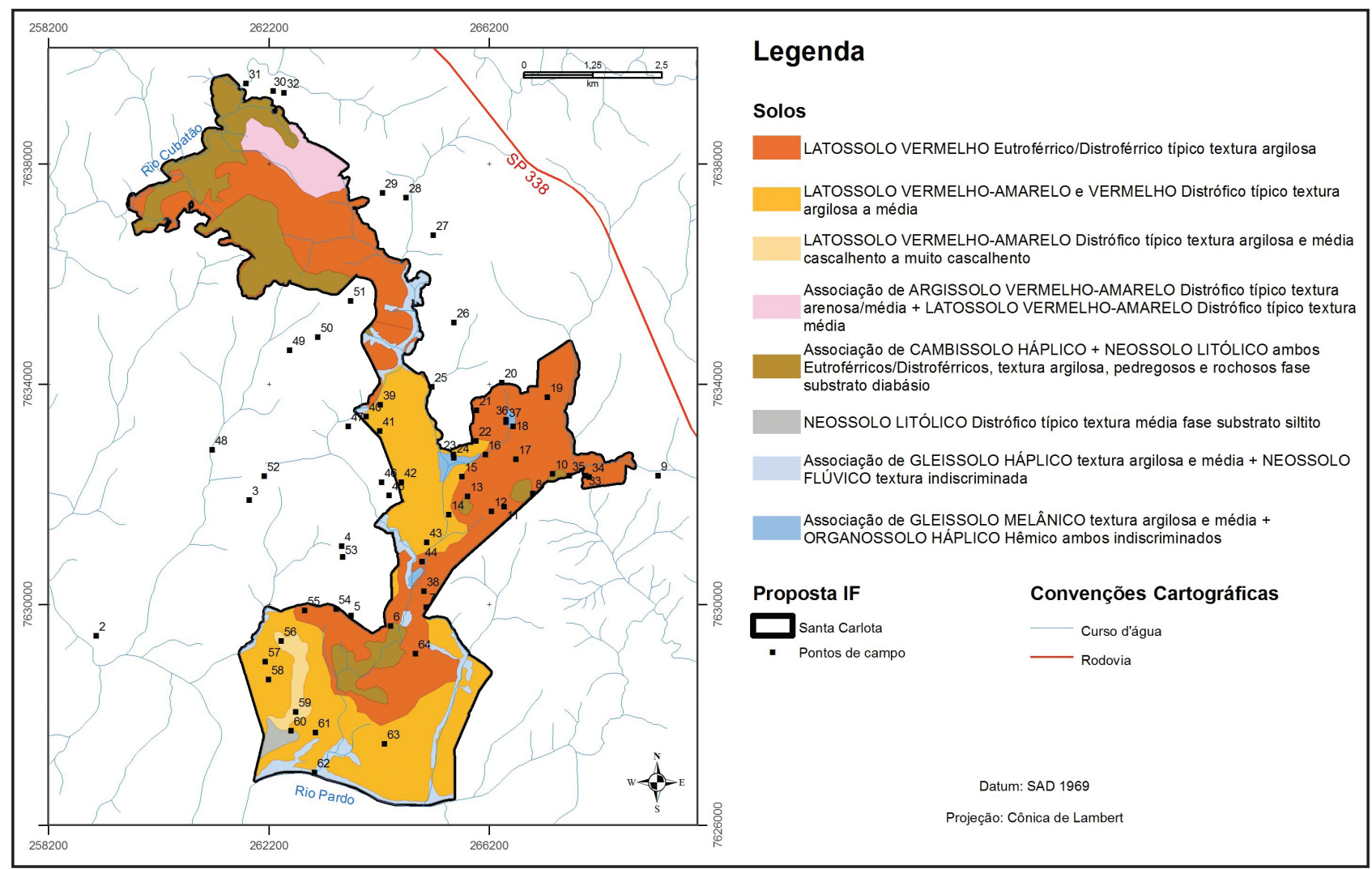

Figura 7. Mapa pedológico da área de estudo.

Figure 7. Pedological map of the study area.

Tabela 2. Extensão e distribuição das unidades de mapeamento de solo da Fazenda Santa Carlota.

Table 2. Extent and distribution of the units of soil mapping in Santa Carlota Farm.

\begin{tabular}{|c|c|c|}
\hline \multirow[b]{2}{*}{ TIPOS DE SOLO } & \multicolumn{2}{|c|}{ ÁREA } \\
\hline & $\begin{array}{l}\text { Absoluta } \\
\text { (ha) }\end{array}$ & $\begin{array}{c}\text { Relativa ao } \\
\text { total }(\%)\end{array}$ \\
\hline LATOSSOLO VERMELHO Eutroférrico/Distroférrico típico textura argilosa & 1.277 & 40,1 \\
\hline $\begin{array}{l}\text { LATOSSOLO VERMELHO-AMARELO e VERMELHO Distrófico típico textura argilosa } \\
\text { a média }\end{array}$ & 1.005 & 31,6 \\
\hline $\begin{array}{l}\text { LATOSSOLO VERMELHO-AMARELO Distrófico típico textura argilosa e média cascalhento } \\
\text { a muito cascalhento }\end{array}$ & 59 & 1,9 \\
\hline $\begin{array}{l}\text { Associação de ARGISSOLO VERMELHO-AMARELO Distrófico típico textura arenosa/ } \\
\text { média + LATOSSOLO VERMELHO-AMARELO Distrófico típico textura média }\end{array}$ & 126 & 4,0 \\
\hline $\begin{array}{l}\text { Associação de CAMBISSOLO HÁPLICO + NEOSSOLO LITÓLICO ambos Eutroférricos/ } \\
\text { Distroférricos, textura argilosa, pedregosos e rochosos fase substrato diabásio }\end{array}$ & 503 & 16,0 \\
\hline NEOSSOLO LITÓLICO Distrófico típico textura média fase substrato siltito & 22 & 0,9 \\
\hline $\begin{array}{l}\text { Associação de GLEISSOLO HÁPLICO textura argilosa e média + NEOSSOLO FLÚVICO } \\
\text { textura indiscriminada }\end{array}$ & 166 & 5,2 \\
\hline $\begin{array}{l}\text { Associação de GLEISSOLO MELÂNICO textura argilosa e média + ORGANOSSOLO } \\
\text { HÁPLICO Húmico ambos indiscriminados }\end{array}$ & 26 & 0,8 \\
\hline TOTAL & 3.184 & 100,00 \\
\hline
\end{tabular}


Tabela 3. Características e atributos dos terrenos amorreados que ocorrem na área. Table 3. Characteristics and attributes of high hills in study area.

\begin{tabular}{|c|c|}
\hline RELEVO & $\begin{array}{l}\text { Morrotes alongados e Espigões - com amplitudes inferiores a } 100 \text { m e inclinação acima } \\
\text { de } 15 \% \text {. Apresenta formas tabulares, com topos angulosos e achatados. Vertentes } \\
\text { ravinadas com perfis retilíneos. Vales fechados. Drenagem de média a alta densidade. }\end{array}$ \\
\hline $\begin{array}{l}\text { SUBSTRATO ROCHOSO, } \\
\text { SEDIMENTOS E } \\
\text { COBERTURAS }\end{array}$ & $\begin{array}{l}\text { Diabásio. } \\
\text { Arenito fino a síltico-argiloso (Formação Piramboia). }\end{array}$ \\
\hline ASSOCIAÇÕES DE SOLOS & $\begin{array}{l}\text { Cambissolo Háplico + Neossolo Litólico, ambos Distro e Eutroférricos; Latossolo } \\
\text { Vermelho Distro e Eutroférrico; todos sobre diabásio; Argissolo Vermelho-Amarelo + } \\
\text { Latossolo Vermelho-Amarelo, ambos Distróficos, sobre arenitos. }\end{array}$ \\
\hline DINÂMICA SUPERFICIAL & Erosão linear (sulcos, ravinas e voçorocas) sobre as rochas sedimentares (arenitos). \\
\hline POTENCIALIDADES & $\begin{array}{l}\text { Solos com fertilidade média a alta. } \\
\text { Alguns dos solos (Latossolos) possuem boa drenagem interna. Porosidade e friabilidade } \\
\text { elevada contribuem para o enraizamento e o cultivo. } \\
\text { O caráter férrico, apresentado pelos Latossolos Vermelhos, os torna aptos para uso em } \\
\text { aterros e pisos de estradas, por ter muito baixa capacidade de contração e expansão. } \\
\text { Além disso, os solos férricos apresentam grande capacidade de adsorver metais pesados, } \\
\text { tornando-os adequados a receber resíduos de metais pesados. }\end{array}$ \\
\hline RESTRIÇÕES & $\begin{array}{l}\text { Nos solos rasos a pouco profundos, por limitar crescimento radicular da vegetação e } \\
\text { pela presença de pedregosidade e rochosidade (Cambisssolos e Neossolos Litólicos). } \\
\text { Suscetível à erosão linear nas áreas sedimentares (Formação Piramboia) e nos solos } \\
\text { com forte gradiente textural entre os horizontes A e B. }\end{array}$ \\
\hline SENSIBILIDADE & Média à alta \\
\hline GEOAMBIENTAL & Terrenos susceptíveis a interferências, devido à erodibilidade dos solos. \\
\hline
\end{tabular}

Tabela 4. Características e atributos dos terrenos colinosos que ocorrem na área.

Table 4. Characteristics and attributes of low hills in study area.

\begin{tabular}{ll}
\hline RELEVO & Colinas médias, com amplitudes inferiores a 100 m e inclinação de $2 \%$ a $15 \%$. Apresentam \\
& topos aplainados e perfil de vertente com segmentos convexos a retilíneos. Vales abertos \\
& a fechados. Presença de planícies interiores restritas e eventualmente de lagoas perenes \\
& ou intermitentes. Densidade de drenagem baixa e média.
\end{tabular}


ROSSI, M. et al. Diagnóstico do meio físico da Fazenda Santa Carlota: solos

Tabela 5. Características e atributos dos terrenos residuais sustentados por litologias particulares que ocorrem na área. Table 5. Characteristics and attributes of the residual lands sustained by singular lithologies in study area.

\begin{tabular}{|c|c|}
\hline RELEVO & $\begin{array}{l}\text { Mesas Basálticas com amplitudes de até } 200 \mathrm{~m} \text { e inclinação de } 2 \% \text { a }>50 \% \text {. Morros } \\
\text { testemunhos isolados e topos aplainados e arredondados. Vertentes retilíneas com } \\
\text { trechos escarpados com exposição de rochas. Vales fechados. Canais erosivos em rocha } \\
\text { e blocos. Média densidade de drenagem. }\end{array}$ \\
\hline $\begin{array}{l}\text { SUBSTRATO ROCHOSO, } \\
\text { SEDIMENTOS E } \\
\text { COBERTURAS }\end{array}$ & Diabásio. \\
\hline ASSOCIAÇÕES DE SOLOS & $\begin{array}{l}\text { Cambissolo+Neossolo Litólico, ambos Distro e Eutroférricos, e Latossolo Vermelho } \\
\text { Distro e Eutroférrico. }\end{array}$ \\
\hline DINÂMICA SUPERFICIAL & Erosão laminar, em sulcos ocasionais, e movimentos de massa. \\
\hline POTENCIALIDADES & $\begin{array}{l}\text { Presença de solos evoluídos (Latossolos) com boa drenagem interna e com elevada } \\
\text { porosidade e friabilidade, favorecendo assim o enraizamento e o cultivo. } \\
\text { Estes ainda apresentam caráter férrico, habilitando-os para uso em aterros e estradas, } \\
\text { por ter muito baixa capacidade de contração e expansão. Além disso, os solos férricos } \\
\text { apresentam grande capacidade de adsover metais pesados, tornando-os adequados a } \\
\text { receber resíduos de metais pesados. }\end{array}$ \\
\hline RESTRIÇÕES & $\begin{array}{l}\text { Solos rasos, com ocorrência de pedregosidade e rochosidade. } \\
\text { Afloramentos rochosos. } \\
\text { Vertentes com altas declividades. } \\
\text { Sujeito a movimentos de massa. } \\
\text { Suscetíveis à erosão laminar e em sulcos. }\end{array}$ \\
\hline SENSIBILIDADE & Alta. \\
\hline GEOAMBIENTAL & Terrenos sensíveis susceptíveis a movimentos de massa e à erosão. \\
\hline
\end{tabular}

Tabela 6. Características e atributos das planícies fluviais que ocorrem na área.

Table 6. Characteristics and attributes of the floodplains which occur in the study area.

\begin{tabular}{|c|c|}
\hline RELEVO & $\begin{array}{l}\text { Planícies Aluviais com inclinação de } 0 \% \text { a } 2 \% \text {. Morfologia continental de terrenos } \\
\text { baixos, mais ou menos planos. }\end{array}$ \\
\hline $\begin{array}{l}\text { SUBSTRATO ROCHOSO, } \\
\text { SEDIMENTOS E } \\
\text { COBERTURAS }\end{array}$ & $\begin{array}{l}\text { Areias inconsolidadas de granulação variável, argila e cascalheiras fluviais em distribuídas } \\
\text { sobre depósitos de calha ou terraços. }\end{array}$ \\
\hline ASSOCIAÇÕES DE SOLOS & $\begin{array}{l}\text { Gleissolo Háplico textura média e argilosa + Neossolo Flúvico Distrófico textura errática } \\
\text { fase floresta aluvial; Gleissolo Melânico textura média e argilosa + Organossolo fase } \\
\text { floresta aluvial. }\end{array}$ \\
\hline DINÂMICA SUPERFICIAL & Deposição, subsidência e erosão fluvial. \\
\hline POTENCIALIDADES & $\begin{array}{l}\text { Relevo aplainado facilitaria a mecanização. } \\
\text { Preservação dos recursos hídricos. }\end{array}$ \\
\hline RESTRIÇÕES & $\begin{array}{l}\text { Solos com baixa a média fertilidade e encharcados. } \\
\text { Suscetibilidade à contaminação e impedimento à mecanização, devido à presença do } \\
\text { lençol freático elevado. } \\
\text { Suscetibilidade a enchentes e inundações, e suscetibilidade a recalques excessivos e } \\
\text { diferenciais, pelo adensamento de argilas moles e turfosas. } \\
\text { Suscetibilidade à erosão fluvial, pelo solapamento das margens dos rios, e ao assoreamento } \\
\text { dos cursos d'água, por sedimentos gerados a partir da erosão à montante. }\end{array}$ \\
\hline SENSIBILIDADE & Alta. \\
\hline GEOAMBIENTAL & $\begin{array}{l}\text { Terrenos frágeis susceptíveis a inundações e enchentes, à erosão fluvial, ao assoreamento } \\
\text { e a contaminações, devido ao encharcamento do solo. }\end{array}$ \\
\hline
\end{tabular}




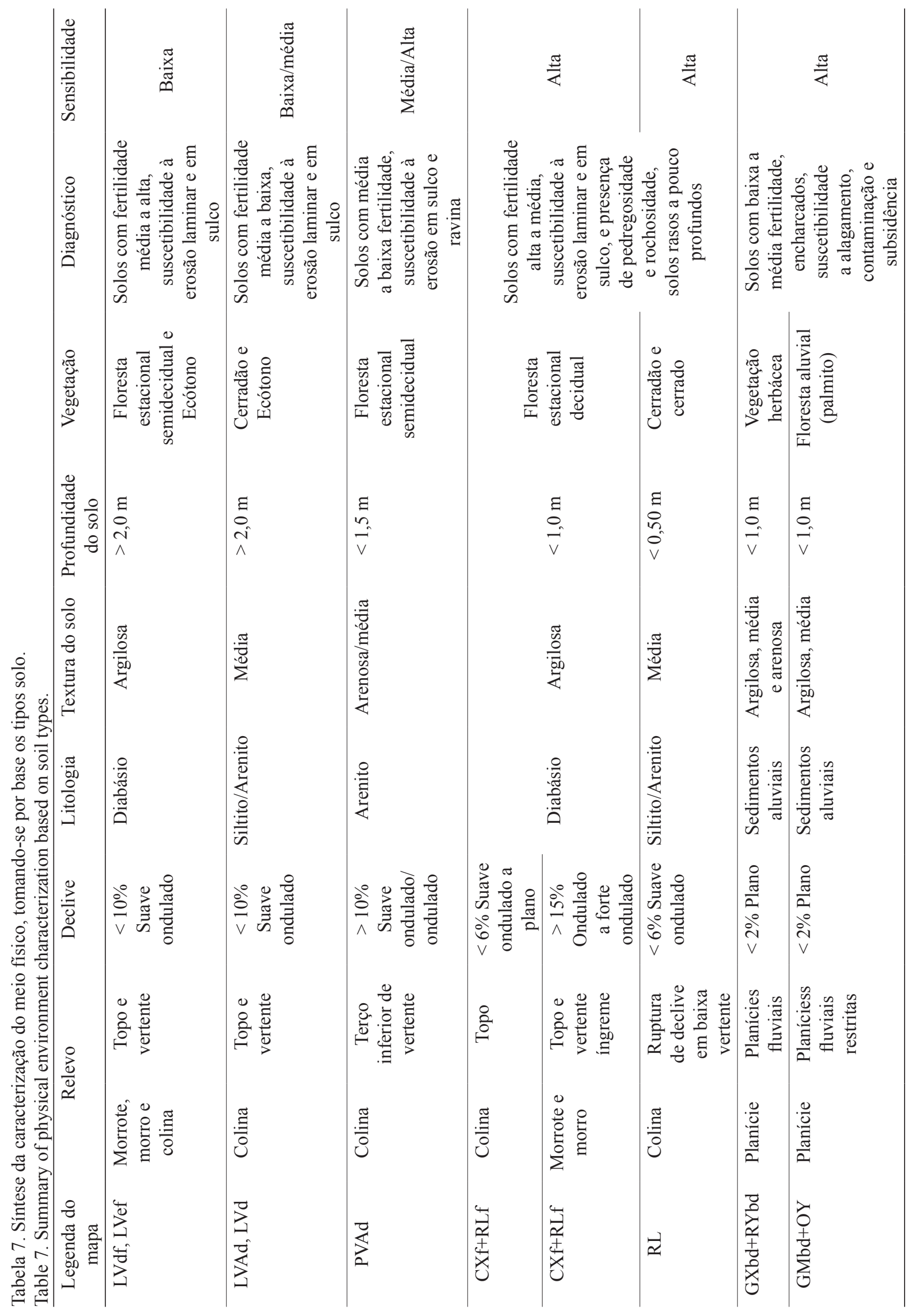


Solos que apresentam cores com matriz 2,5YR ou mais vermelho na maior parte dos primeiros $100 \mathrm{~cm}$ do horizonte B (inclusive BA). São, em geral, de textura média a argilosa, porosos, bem permeáveis e com características físicas favoráveis ao desenvolvimento radicular. Quimicamente, o horizonte B comporta-se como ácido, mesoférrico, distrófico e/ou álico.

\section{Latossolo Vermelho Férrico}

Também ocorre em relevo colinoso, com declives inferiores a 10\% e classe textural argilosa ( $>35 \%$ de argila), que difere do Latossolo Vermelho por apresentar teores de $\mathrm{Fe}_{2} \mathrm{O}_{3}$ entre 18 e 36\%, permitindo o desenvolvimento de Floresta Estacional Semidecidual e Ecótono, em sua maioria. Na área, se desenvolvem em litologia de diabásio.

O horizonte B comporta-se como Distroférrico ou Eutroférrico. O horizonte A é moderado ou proeminente.

Latossolo Vermelho-Amarelo

Ocorre, normalmente, nas baixas vertentes ou próximo a cabeceiras e calhas de drenagem. Apresenta teores de $\mathrm{Fe}_{2} \mathrm{O}_{3}$ entre 8 e 11\%, em que se desenvolvem, normalmente, cerradão e ecótono. Na área, se desenvolvem em litologia de siltito e arenito, e destas em contato com o diabásio.

Argissolo Vermelho-Amarelo

Compreende solos constituídos por material mineral, que apresenta como característica diferencial a presença de horizonte B textural de argila de atividade baixa, imediatamente abaixo do horizonte A. São de profundidade variável, de classe moderada a imperfeitamente drenados, de cores avermelhadas a amareladas. A textura é arenosa/média, com cores de matriz entre 7,5YR e 5YR na maior parte dos primeiros $100 \mathrm{~cm}$ do horizonte B (inclusive BA). Ocorrem em relevo colinoso nas vertentes e nos fundos de vales com declives superiores a 10\% em Floresta Estacional Semidecidual, sobre litologia de arenito.

\section{Gleissolos}

Compreendem solos hidromórficos constituídos por material mineral e que apresentam horizonte glei, dentro dos primeiros $150 \mathrm{~cm}$ da superfície do solo, com cores de redução ou neutras. Os solos dessa classe encontram-se permanente ou periodicamente saturados por água, salvo se artificialmente drenados. Apresentam textura variada, arenosa, média e argilosa. Ocorrem associados ao Neossolo Flúvico e ao Organossolo. A associação é encontrada em floresta aluvial, quando o excesso de água é corrente e em relevo plano, e em vegetação herbácea, quando o excesso de água é estagnado ou lento.

Gleissolo Háplico

Apresenta horizonte A moderado, de textura média a argilosa, com atividade de argila baixa. Solo que ocorre em floresta aluvial com gramínea.

Gleissolo Melânico

Acresce-se a presença de horizonte $\mathrm{H}$ hístico, com menos de $40 \mathrm{~cm}$ de espessura, ou horizonte A húmico, proeminente ou chernozêmico. Solo que ocorre em floresta aluvial com palmeiras (palmito).

\section{Neossolo Flúvico}

Solos derivados de sedimentos aluviais que se apresentam como deposição de camadas ou estratos aleatórios, com variação textural acentuada (com exceção em estratos espessos), e a distribuição irregular do carbono ao longo dos $200 \mathrm{~cm}$ da superfície do solo (Oliveira, 2008). Ocorrem em relevo plano, são pouco evoluídos e constituídos por material mineral ou por material orgânico com menos de $20 \mathrm{~cm}$ de espessura, não apresentando qualquer tipo de horizonte B diagnóstico. Horizonte glei ou horizontes de coloração pálida, variegada ou com mosqueados abundantes ou comuns de redução, se ocorrem abaixo do horizonte A, e devem estar a profundidades superiores a $150 \mathrm{~cm}$. Apresentam textura variada. Solo que ocorre em floresta aluvial com gramínea. 


\section{Organossolo}

São solos mal drenados, com lençol freático aflorante ou subaflorante. Compreende solos com teores de $\mathrm{C}$ elevados, ácidos, constituídos por camadas espessas de matéria orgânica sobre material mineral, com Gleização. O horizonte superficial $\mathrm{O}$ chega a possuir mais que 1,0 $\mathrm{m}$ de espessura, com cores escuras. Esses solos ocorrem em áreas abaciadas nas planícies fluviais e associados a cursos d'água, locais permanentemente encharcados, com vegetação de floresta aluvial com palmeiras (palmito).

\section{Cambissolo}

Compreende solos minerais não hidromórficos, com horizonte $\mathrm{B}$ incipiente e com sequência de horizontes $\mathrm{A}-\mathrm{Bi}-\mathrm{C}$, com pequena diferenciação entre os horizontes. São solos que variam de rasos $(<0,50$ $\mathrm{m})$ a pouco profundos $(0,50-1,00 \mathrm{~m})$, pouco desenvolvidos e moderadamente drenados, e apresentam minerais primários e restos de fragmentos de rocha na massa do solo e, muitas vezes, blocos e matacões na superfície. Quimicamente, são eutróficos a mesodistróficos.

Ocorrem associados a relevo que varia de ondulado a escarpado, no relevo de morrotes e nos topos no relevo de colinas, juntamente com os neossolos litólicos de diabásio, onde afloram.

Neossolo Litólico

São solos minerais não hidromórficos, rudimentares, pouco evoluídos, rasos (menor que $50 \mathrm{~cm}$ até o substrato rochoso), com horizonte $\mathrm{A}$ assentado diretamente sobre a rocha matriz ou sobre horizonte $\mathrm{C}$ pouco espesso. São, portanto, solos com horizonte A - R ou A - C - R. Estão localizados em vertentes bem inclinadas no relevo de morrotes e em topos do relevo de colinas, onde aflora o diabásio. Há, ainda, ocorrência de afloramento e presença de Neossolo Litólico ao sul da área, na presença de siltito. Nas duas litologias, os Neossolos Litólicos associam-se com os Cambissolos em pequenas áreas.

A maior limitação dos Neossolos Litólicos é a pequena profundidade efetiva, que limita o desenvolvimento radicular das plantas, reduzindo a capacidade de sustentabilidade da vegetação, principalmente quanto aos aspectos de disponibilidade hídrica. Quando em áreas declivosas, são muito suscetíveis à erosão (Oliveira et al., 1999). A condição de desmatamento ou de pouca cobertura vegetal, quando aliada às precipitações concentradas, facilita a formação de erosão dos tipos laminar e em sulcos, e, quando em relevos acidentados, há movimentos de massa rápidos.

A Tabela 2 apresenta as unidades Latossolo Vermelho Férrico com aproximadamente $40 \%$ da área e os Latossolos Vermelho-Amarelo/Vermelho em diferentes litologias, com aproximadamente 35\% da área, sendo os demais distribuídos em menores proporções entre os Cambissolos e Neossolos Litólicos (16\%), e Argissolos, Gleissolos, Neossolos Flúvicos e Organossolos perfazendo 9\%, em conjunto.

A seguir, são apresentadas informações do meio físico contidas nas Tabelas 3 a 6 , de forma mais detalhada, e na Tabela 7, como forma de síntese dos principais atributos da região analisados, que interpreta a sensibilidade aos processos de erosão e sedimentação, atribuindo graus baixo, médio e alto aos terrenos.

No centro/norte da área estudada, ocorre relevo de morros com inclinações fortes, em que dominam solos pouco profundos e rasos, argilosos e férricos (Cambissolos e Neossolos Litólicos - Figuras 8, 9 e 10) nas vertentes e no topo, sob litologia de diabásio. Na baixa vertente, desenvolvem-se solos profundos também argilosos, dominando os latossolos vermelhos férricos (Tabela 3). Os processos dominantes aqui são os sulcos, ravinas e voçorocas, principalmente nas áreas de ocorrência de rochas sedimentares, implicando em baixa potencialidade dos terrenos pela profundidade efetiva dos solos, pela fertilidade, pelo potencial erosivo e, em casos restritos, pelo declive acentuado, traduzindo em sensibilidade geoambiental de grau médio a alto.

No relevo colinoso e no relevo residual (Tabelas 4 e 5), nos topos e terços superiores, com inclinação inferior a $10 \%$ e influência do diabásio, dominam os Latossolos Vermelhos Férricos e não Férricos de textura argilosa; já no relevo de terço inferior de vertente, acresce-se o Latossolo Vermelho-Amarelo, influenciado pelas linhas e/ou cabeceiras de drenagem (Figuras 10 e 11). Nesses setores, alternam-se o Cerradão, o Ecótono e a Floresta Estacional, sendo que há indícios de que a fertilidade e a retenção de umidade são os fatores que determinam o estabelecimento da vegetação. Há topos com afloramentos de diabásio e formação de Neossolos 


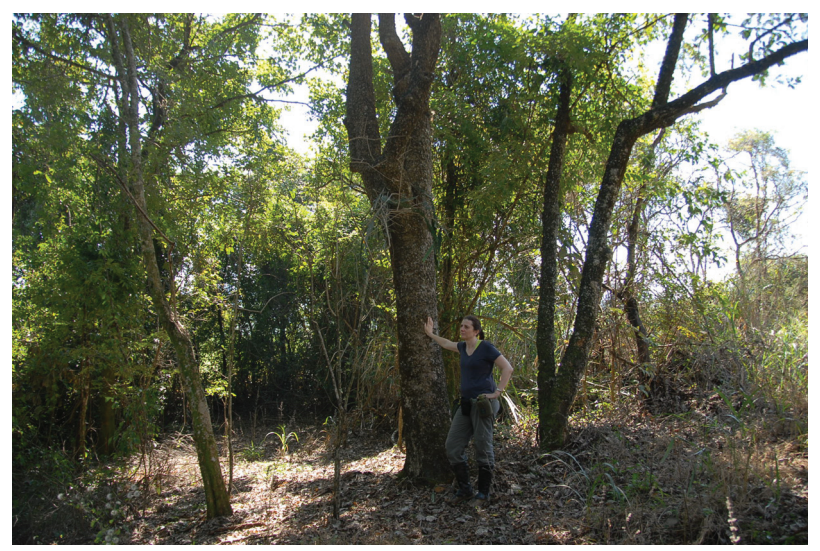

Figura 8. Floresta Estacional Decidual sobre solos rasos, Neossolo Litólico, com substrato de diabásio.

Figure 8. Seasonal Semideciduous Forest on shallow soils, Lithic Udorthents, with diabase substrate.

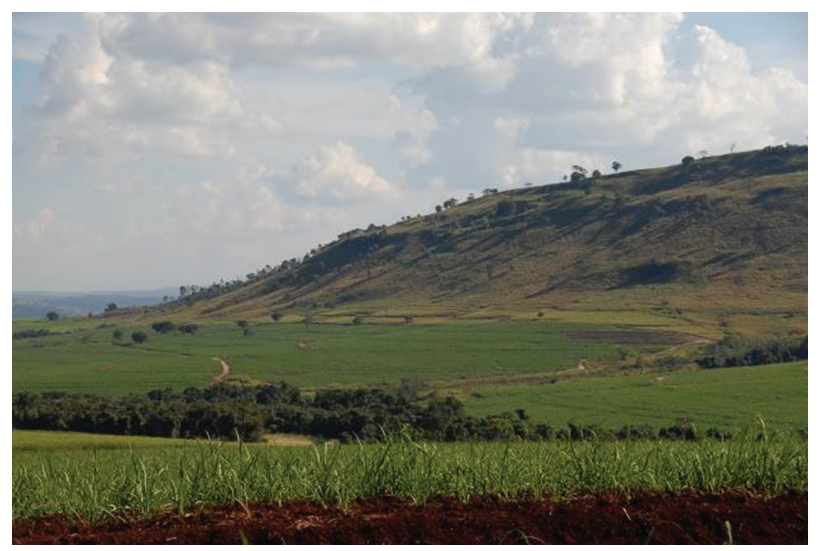

Figura 10. Relevo colinoso com Latossolo Vermelho Férrico e relevo residual, onde dominam solos pouco profundos, Cambissolos e Neossolos Litólicos de diabásio.

Figure 10. Relief of low hills with Rhodic Hapludoxes and residual relief where shallow soils, Inceptisols and Lithic Ustorthent, are predominant.

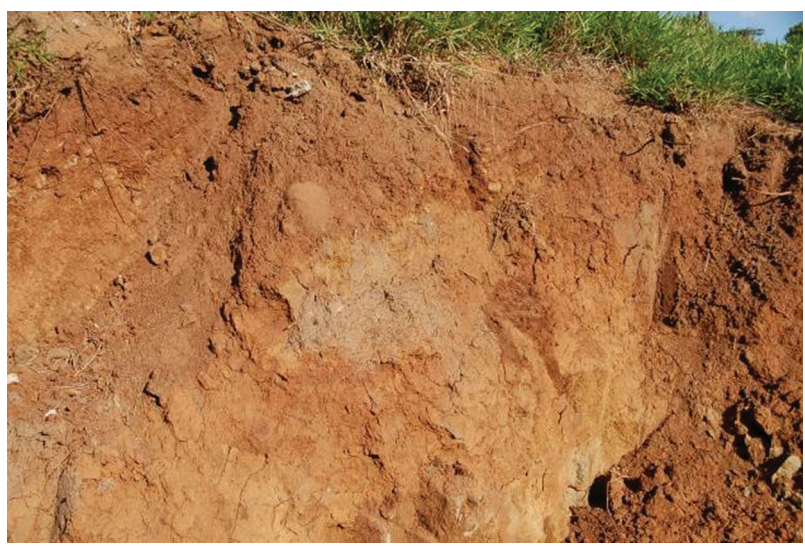

Figura 9. Exemplo de Cambissolo Férrico em relevo de morros sobre diabásio.

Figure 9. Example of Inceptsol with high content of iron oxides (ferric) on a relief of high hills overlying diabase.

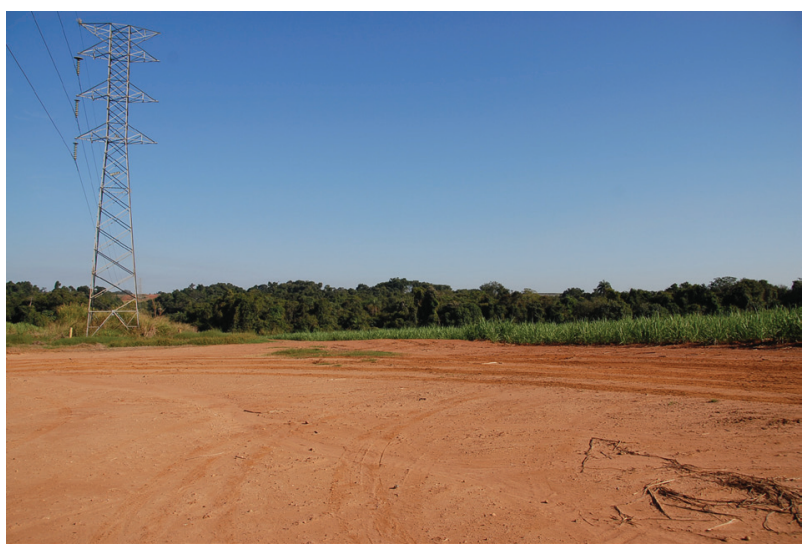

Figura 11. Relevo colinoso apresentando solos profundos de textura média, Latossolo Vermelho, em substrato arenítico. Figure 11. Hilly relief showing deep loamy soils, Rhodic Haplustox, overlying sandstone.

Litólicos, solos rasos, de textura argilosa, onde domina a Floresta Estacional Decidual. Também dominam nos setores de colinas, como dinâmica superficial, os processos de erosão (sulcos, ravinas e voçorocas), implicando em baixa potencialidade dos terrenos pela fertilidade, presença de textura binária nos solos e potencial erosivo. A presença de Latossolos profundos e do relevo aplainado favorece o manejo, traduzindo em sensibilidade geoambiental de grau médio a baixo. No caso do relevo residual, a potencialidade restringe-se pela pouca profundidade efetiva dos solos, pelos declives acentuados e pelas possibilidades de movimentos de massa nas vertentes mais íngremes, imprimindo uma sensibilidade geoambiental de grau alto.

Nos fundos de vale, há presença de planícies restritas com formação de Organossolos e Gleissolos de textura argilosa a média (Tabela 6), em que domina a vegetação de áreas alagadiças, a Floresta Estacional Semidecidual Aluvial (várzea) (Figuras 12, 13 e 14). Nesses setores, quando os solos são mais encharcados e a água permanece mais estagnada, a vegetação é herbácea, enquanto que, no domínio dos Organossolos, que chegam a ocupar o sopé das vertentes, a Floresta Estacional Semidecidual Aluvial com palmeiras destaca-se; nesse caso, o encharcamento parece ser mais sazonal e fluídico no estabelecimento da vegetação. Os processos de dinâmica superficial, nesse trecho, restringem-se a deposição, subsidência e erosão fluvial, implicando em baixa potencialidade dos terrenos pela presença de lençol freático aflorante, que ficam sujeitos a encharcamento e 

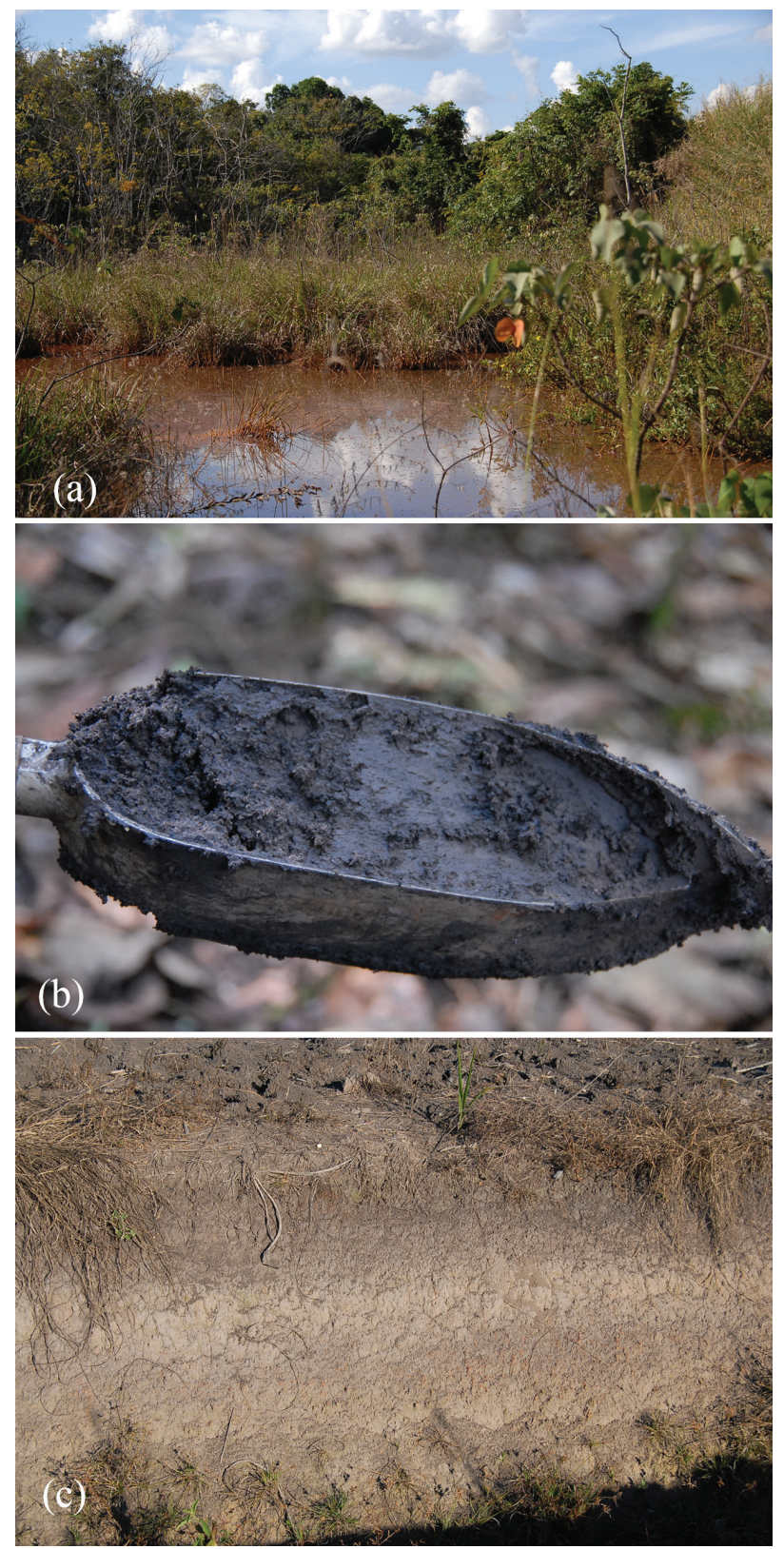

Figura 12. Planície fluvial (a) com solos hidromórficos, Gleissolo argiloso (b) e de textura média (c).

Figure 12. Floodplain (a) with hydromorphic, clayey (b) and loamy (c) Ultisols.

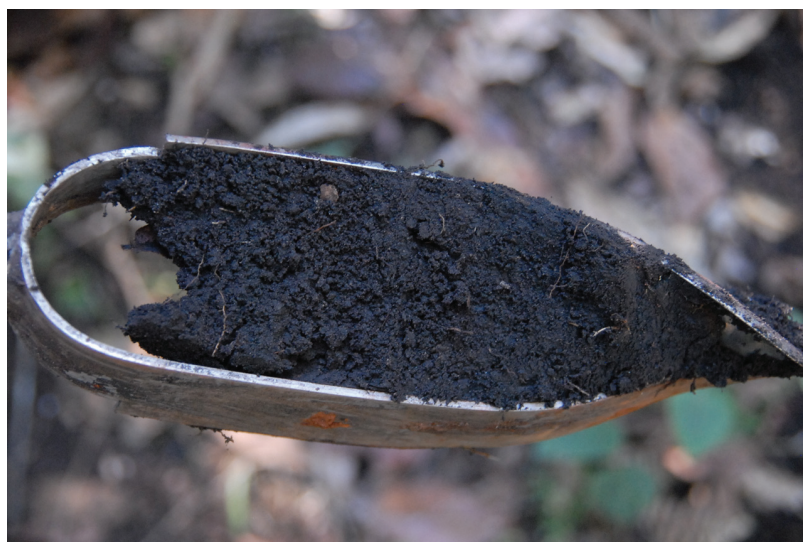

Figura 13. Aspecto de solo orgânico em planície fluvial com floresta estacional aluvial com palmito.

Figure 13. Aspect of organic soil in a floodplain with seasonal Deciduous Alluvial Forest with ‘jussara’ palm.

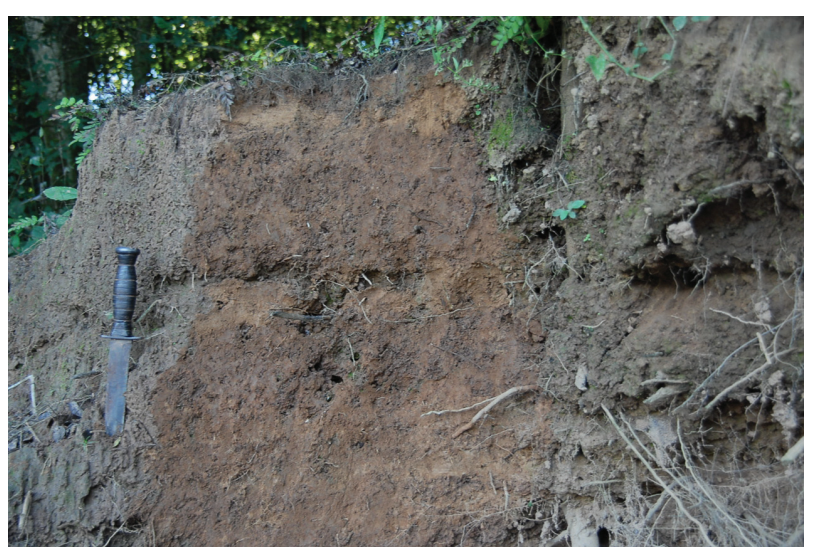

Figura 14. Neossolo Flúvico na planície do Rio Pardo. Figure 14. Ustifluvent on the Pardo river floodplain.

inundações, recalques e adensamento de argilas moles e turfosas. São áreas normalmente de proteção permanente, traduzindo em sensibilidade geoambiental de grau alto.

A Tabela 7 mostra resumidamente, de forma concisa, os dados apresentados e discutidos nas tabelas anteriores. Assim, nos topos e terços superiores de colina, com inclinação inferior a 10\% e influência do arenito Piramboia, há predominância de Latossolos Vermelho-Amarelos de textura média grossa, passando a Argissolos Vermelho-Amarelos de textura arenosa/média vertente abaixo. Nesses setores, há forte presença de Floresta Estacional Semidecidual e Cerradão.

Nas áreas de domínio do siltito, em colina, há predominância de Latossolos Vermelho-Amarelos de textura média, onde domina o Cerradão. Em zonas restritas de terço inferior de vertente, em ruptura de declive, 


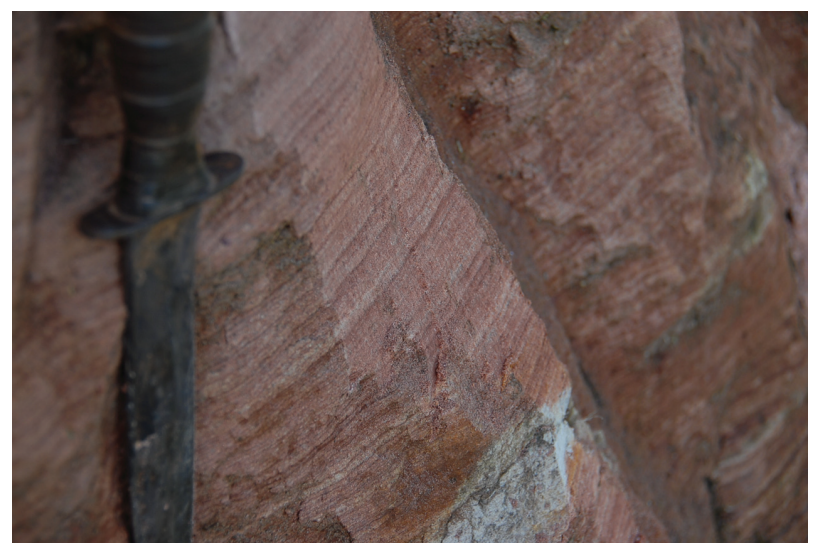

Figura 15- Exemplo de arenito, em que se desenvolvem Argissolo de textura arenosa/média e Latossolo de textura média em relevo amorreado.

Figure 15. Features of a sandstone on a relief of high hills, where sandy over loamy Ultisols and loamy Oxisols are found.

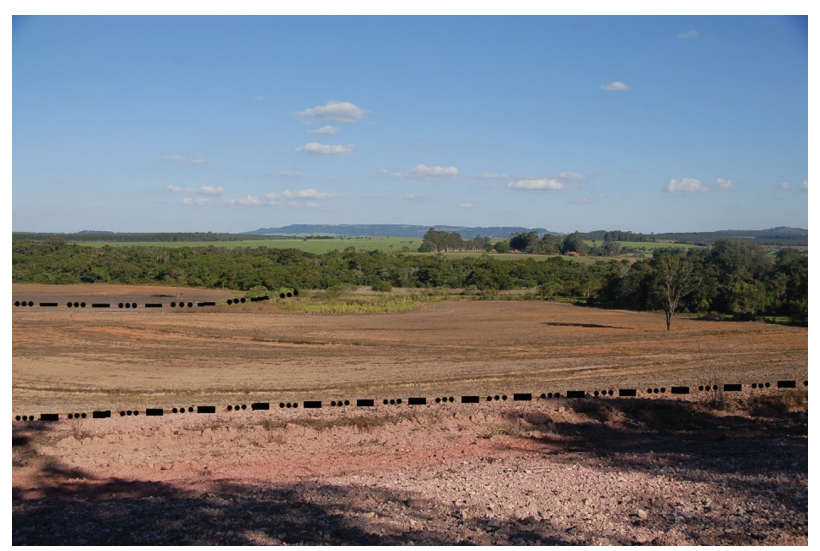

Figura 17. Em primeiro plano, Neossolo Litólico de siltito; no centro da foto, Latossolo Amarelo a Vermelho-Amarelo, e na faixa mais escura, ao fundo, Gleissolo próximo à planície do Rio Pardo.

Figure 17. In the foreground, Lithic Ustorthent developed from siltstone; in the middle, Typic and Rhodic Haplustox; and at the darker soil strip near the Pardo River floodplain on the background, Aquent.

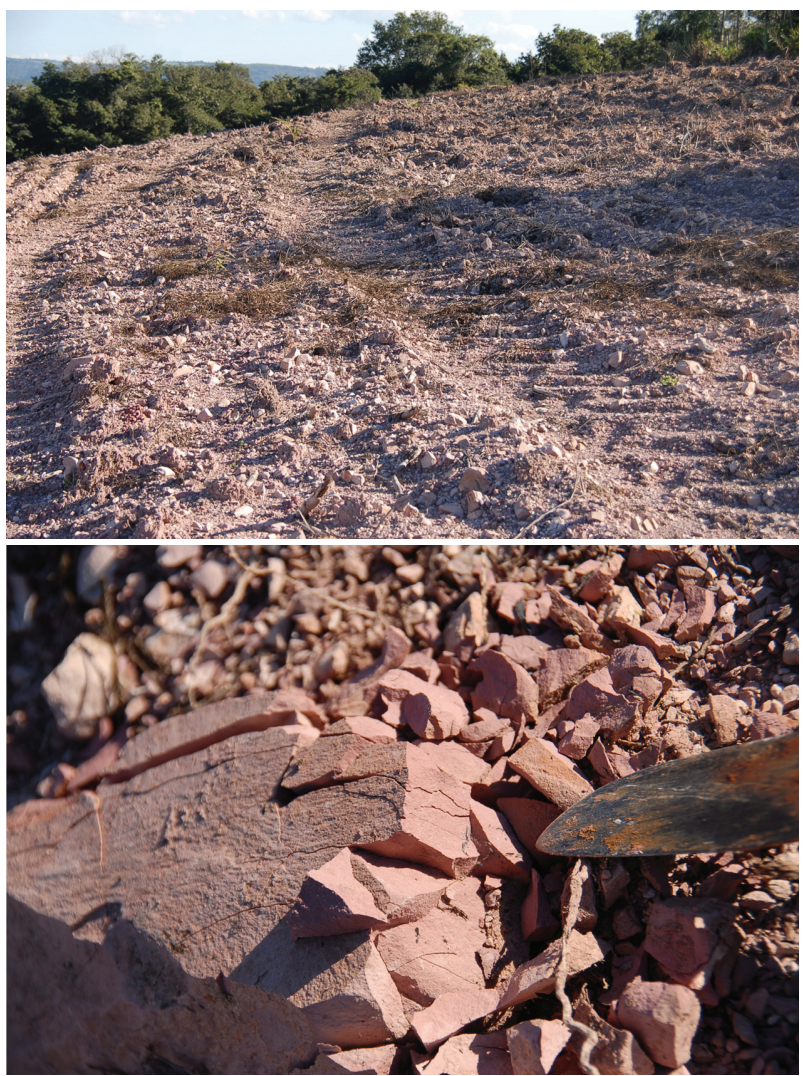

Figura 16. Área de afloramento de siltito, onde se desenvolvem Neossolos Litólicos de textura média, em ruptura de declive de baixa vertente no relevo colinoso.

Figure 16. Siltstone outcrop on low hill relief where loamy Lithic Ustorthents are found on the slope break.

o siltito chega a aflorar (Figuras 15,16 e 17) e permite o desenvolvimento de Neossolos Litólicos, solos rasos, normalmente de textura média. Segue-se com o aprofundamento do solo e a formação de Latossolos VermelhoAmarelos a Amarelos, terminando em fundo de vale com gleissolos de textura média.

Há áreas com presença de cascalheiras, onde dominam seixos quartzosos incrustadas no siltito, com domínio de material latossólico de textura média cascalhenta a muito cascalhenta. Por vezes, a cascalheira aflora onde ocorreu exploração em passado recente. A vegetação aqui é de Ecótono.

Nas planícies fluviais desenvolvidas sobre os depósitos sedimentares, ocorre associação de Gleissolo de textura argilosa a média e Neossolo Flúvico de textura arenosa/média, onde estão presentes a vegetação de várzea graminoide e a floresta aluvial. 


\section{CONCLUSÃO}

A área apresenta condições do meio físico adequadas ao uso agrossilvopastoril, principalmente nos relevos mais aplanados e colinosos, de domínio de diabásio e arenitos. Cuidados com a conservação dos solos são primordiais em qualquer litologia ou tipo de solo, uma vez que a erosão pode se instalar a qualquer tempo, se intensificando no relevo com maior energia (maior declive), quando descoberto de vegetação.

Alguns solos são mais suscetíveis aos processos de erosão, como os mais rasos (Cambissolos e Neossolos Litólicos), os que apresentam textura binária (Argissolos) e os de textura mais grosseira ou com cascalho (Latossolos textura média grossa). Outros processos que devem ser avaliados são os de movimentos de massa, nas vertentes de altas declividades, onde ocorrem os Cambissolos e Neossolos Litólicos, e os processos de sedimentação, no caso dos Gleissolos, Neossolos Flúvicos e Organossolos, que recebem todo o material erodido à montante, sendo muito suscetíveis a contaminação, subsidência e erosão de canal.

Relativamente ao meio físico, a área estudada apresenta características favoráveis para tornar-se Unidade de Conservação.

\section{REFERÊNCIAS BIBLIOGRÁFICAS}

ALMEIDA, F. F. M. et al. Mapa geológico do Estado de São Paulo. São Paulo: Instituto de Pesquisas Tecnológicas, 1981. Escala 1:500.000. Nota Explicativa. (v. 1).

BISTRICHI, C. A. et al. Mapa geológico do Estado de São Paulo. São Paulo: Instituto de Pesquisas Tecnológicas, 1981. Escala 1:500.000.

NAKAZAWA, V. A. et al. Carta Geotécnica do Estado de São Paulo: escala 1:500 000. São Paulo: Instituto de Pesquisas Tecnológicas, 1994. v. 1 e 2. (Publicação IPT, 2089).

Carta geotécnica do Estado de São Paulo. São Paulo: Instituto de Pesquisas Tecnológicas, 1994. Escala 1:500.000. (v. 2).

OLIVEIRA, J. B. et al. Mapa pedológico do Estado de São Paulo: legenda expandida. Campinas: Instituto Agronômico; Rio de Janeiro: Embrapa Solos, 1999. Escala 1:500000.

OLIVEIRA, J. B. Pedologia aplicada. 3. ed. Piracicaba: FEALQ, 2008.

PERrotTA, M. M. et al. Mapa geológico do Estado de São Paulo. São Paulo: CPRM, 2005. Escala 1:750.000. (Programa da Geologia do Brasil - PGB).

PIRES NETO, A. G. As abordagens sintético- histórica e analítico- dinâmica, uma proposição metodológica para a geomorfologia. 1992. 302 f. Tese (Doutorado)-Departamento de Geografia, Universidade de São Paulo, São Paulo, 1992.

PONÇANO, W. L. et al. Mapa geomorfológico do Estado de São Paulo. São Paulo: Instituto de Pesquisas Tecnológicas do Estado de São Paulo, 1981. v. 1 e 2. Monografia 5. Escala 1:1.000.000

. Mapa geomorfológico do Estado de São Paulo. São Paulo: Instituto de Pesquisas Tecnológicas, 1981. Nota Explicativa. (v. 1).

ROSS, J. L. S.; MOROZ, I. C. Mapa geomorfológico do Estado de São Paulo: mapas e relatórios. São Paulo: Laboratório de Geomorfologia (Departamento Geografia FFLCH/USP), Laboratório de Cartografia GeotécnicaGeologia Aplicada (IPT), FAPESP, 1997. 
ROSSI, M. et al. Diagnóstico do meio físico da Fazenda Santa Carlota: solos

ROSSI, M. et al. Relação solos/vegetação em área natural no Parque Estadual de Porto Ferreira, São Paulo. Revista do Instituto Florestal, v. 17, n. 1, p. 45-61, 2005.

SANTOS, B. R. G.; ROSSI, M.; KANASHIRO, M. M. estudo de implantação de uma unidade de conservação na região compreendida entre Magda e Meridiano: caracterização e mapeamento do meio físico. In: Seminário de Iniciação Científica do Instituto Florestal, 5., 2011, São Paulo. Anais... São Paulo: Instituto Florestal, 2011.p. 1-1.

SANTOS, R. D. et al. Manual de descrição e coleta de solo no campo. 5. ed. Viçosa: SBCS/EMBRAPA-CNPS, 2005. $92 \mathrm{p}$.

SANTOS, H. G. et al. Sistema brasileiro de classificação de solos. 3. ed. rev. ampl. Brasília: Embrapa, 2013.

VILLELA, F. N. J. Geological, geomorphological and climatic aspects of Serra Geral do Tocantins Ecological Station, Brazil. Journal of Earth Science and Engineering, 2012.

ZORNOFF, D. R.; ROSSI, M.; KANASHIRO, M. M. Estudo do meio físico como subsídio para criação de Unidade de Conservação (UC) em Peruíbe-Itanhaém. Revista Geográfica de América Central, v. 2, n. 47E, p. 1-12, 2011. Edição Especial. Disponível em: <http://www.revistas.una.ac.cr/index.php/geografica/article/view/2445>. 